\title{
Plasma amyloid beta measurements - a desired but elusive Alzheimer's disease biomarker
}

\author{
Jon B Toledo, Leslie M Shaw and John Q Trojanowski*
}

\begin{abstract}
Cerebrospinal fluid and positron emission tomography biomarkers accurately predict an underlying Alzheimer's disease (AD) pathology; however, they represent either invasive or expensive diagnostic tools. Therefore, a blood-based biomarker like plasma amyloid beta (A $)$ that could correlate with the underlying $A D$ pathology and serve as a prognostic biomarker or an AD screening strategy is urgently needed as a cost-effective and non-invasive diagnostic tool. In this paper we review the demographic, biologic, genetic and technical aspects that affect plasma $A \beta$ levels. Findings of cross-sectional and longitudinal studies of plasma $A \beta$, including autosomal dominant AD cases, sporadic AD cases, Down syndrome cases and population studies, are also discussed. Finally, we review the association between cerebrovascular disease and $A \beta$ plasma levels and the responses observed in clinical trials. Based on our review of the current literature on plasma $A \beta$, we conclude that further clinical research and assay development are needed before measures of plasma $A \beta$ can be interpreted so they can be applied as trait, risk or state biomarkers for $\mathrm{AD}$.
\end{abstract}

\section{Introduction}

Alzheimer's disease (AD) is the most common underlying cause of dementia globally, and the leading cause of years lost to disability in high-income countries as well as the second greatest cause of this worldwide according to the World Health Organization. A definite diagnosis of AD can only be established by postmortem studies that demonstrate the presence of extracellular amyloid plaques

\footnotetext{
*Correspondence: trojanow@mail.med.upenn.edu
}

Department of Pathology and Laboratory Medicine, Institute on Aging, Center for Neurodegenerative Disease Research, University of Pennsylvania School of Medicine, Philadelphia, PA 19104, USA and intracellular tau neurofibrillary tangles [1]. The measurement of the neuropathologic hallmarks of $\mathrm{AD}$, namely tau and amyloid beta $(A \beta)$, in cerebrospinal fluid (CSF) has been shown to be a reliable diagnostic biomarker for $\mathrm{AD}$ [2], but it would be attractive to have less invasive AD biomarkers, such as those that can be measured in plasma. Positron emission tomography (PET) using florbetapir-F18 (AV-45) or Pittsburgh Compound-B-C11 ( $\mathrm{PiB})$ as radiotracers reflects fibrillar brain amyloid deposits and is deemed a reliable method to measure brain amyloid plaque burden [3,4], but cost and availability of PET biomarker measures are drawbacks associated with this diagnostic strategy. Therefore, the measurement of $A \beta$ in plasma would be the least invasive and most cost-effective biomarker assay. In addition, blood samples could readily be obtained in nonspecialized facilities and sent to specialized laboratories to conduct the measurements. However, published results on the correlation of plasma $A \beta$ with the presence of $\mathrm{AD}$ are contradictory and plasma $\mathrm{A} \beta$ measurements are subject to more sources of variability than CSF A $\beta$ measurements [5]. Below we will summarize the demographic, biological and technical aspects related to $A \beta$ plasma measures, the results of cross-sectional and longitudinal studies in populations with sporadic $\mathrm{AD}$ and $\mathrm{AD}$ due to autosomal dominant genetic inheritance, and application of these measurements in clinical trials.

\section{$A \beta$ distribution in blood, CSF and brain}

$A \beta$ production and correlation between plasma, CSF and parenchymal $A \beta$ measurements

$A \beta$ is a byproduct of $A \beta$ precursor protein (APP) metabolism that is generated by nearly all cells, and amyloid plaques are the result of the deposition of mainly $A \beta_{1-40}$ and $A \beta_{1-42}$ in the brain, although other species of $A \beta$ are also present [6]. The mechanism leading to $A \beta$ deposition differs in subjects for whom this occurs on a genetic basis, leading to familial AD (FAD), versus those who develop sporadic $\mathrm{AD}$. In autosomal dominantly inherited forms of $\mathrm{AD}$, the main mechanism is an increased production of $A \beta$ species [7], while the consensus is that there is a decreased $A \beta$ clearance in sporadic forms of 
$\mathrm{AD}$, which is modulated by the apolipoprotein $\mathrm{E}$ (APOE) genotype $[8,9]$.

The blood-brain barrier and the blood-CSF barrier regulate the passage of solutes between blood and the central nervous system $(\mathrm{CNS})$, including $A \beta$. Although there are a number of receptors that are implicated in the influx (for example, receptor of advanced glycation end products) and efflux (for example, low-density lipoprotein receptor, low-density lipoprotein receptor-related protein 1 and 2, P-glycoprotein, low-density and very low-density lipoprotein receptor) of $A \beta$ through the blood-brain barrier, most of the studies that compared plasma $A \beta$ levels with their CSF counterparts [10-13] or the binding of PET A $\beta$ radiotracers $[10,14]$ have found no or low correlations between $A \beta$ plasma measurements and CSF A $\beta$ and PET amyloid plaque measurements. On the other hand, CSF and PET values show a high inverse correlation [10,15,16], although CSF ELISA/Luminex assays measure soluble $\mathrm{A} \beta$ and $\mathrm{PIB} / \mathrm{AV}-45$ PET measure insoluble fibrillar $A \beta$ deposition. However, one study has described a stronger correlation between plasma $A \beta$ and PET PiB measurements [17].

\section{Origin, distribution and clearance of $A \beta$ in plasma}

There are several factors that can explain the low correlation between plasma and CSF A $\beta / P E T$ amyloid plaque measurements. First, $A \beta$ species in the CSF and the CNS interstitial fluid originate in the CNS. CNS A $\beta$ is then thought to diffuse from interstitial fluid into the CSF, while passage of $A \beta$ through the blood-brain barrier is limited. In addition, $A \beta$ in plasma and blood does not originate only in the brain since it also is the product of APP metabolism in skeletal muscle, pancreas, kidney, liver, vascular walls, lung, intestine, skin and several glands and APP can be found in almost all peripheral cells [18-20]. In addition, most of the $A \beta_{1-40}$ and $A \beta_{1-42}$ in plasma are bound to several proteins (that is, apolipoprotein A-I, A-IV, E and J, $\alpha 2$-macroglobulin, complement factors, immunoglobulins, transthyretin, apoferritin and serum amyloid $\mathrm{P}$ component) and erythrocytes $[19,21]$. Finally, platelets are another important source of $A \beta_{1-40}$ and $A \beta_{1-42}$ in plasma [19] and activated platelets release APP and A $\beta$ [22]. Therefore, it is not surprising that $A \beta$ plasma values may only partially reflect altered APP metabolism or A $\beta$ in the CNS since there is no evidence that $\mathrm{AD}$ is a systemic $\mathrm{A} \beta$ amyloidosis. While correlations between undiluted, diluted and cell bound plasma samples have been reported by some investigators to be high, the diagnostic utility of measuring $A \beta$ at different dilutions or in different fractions remains uncertain [23]. Finally, regarding the elimination of plasma $\mathrm{A} \beta$, animal models have implicated the liver as the major organ responsible for the clearance of $A \beta$ from plasma [24], followed by renal clearance [25].

\section{Demographic, clinical, genetic and technical issues affecting $A \beta$ levels and measurements}

Demographic, genetic diagnostic and assay related factors affecting $A \beta$ plasma levels

Most studies have described a strong association between older age and higher levels of plasma $A \beta[10,26-31]$. This association has not been established in Down syndrome (DS) subjects, and there are conflicting results, with some studies finding an association [32,33] and others not $[34,35]$. Two studies have evaluated the heritability of $A \beta$ plasma levels. The paper by Ertekin-Taner et al. found a higher heritability (54\% for $\mathrm{A} \beta_{1-40}$ and $73 \%$ for $\mathrm{A} \beta_{1-42}$ ) [36] than the one by Ibrahim-Verbaas et al. (23\% for $A \beta_{1-40}$ and $30 \%$ for $A \beta_{1-42}$ ) [37]. None of the studies found that APOE genotype explained a significant amount of the heritability, but the study by Ibrahim-Verbaas et al. found an association between SNPs located at the presenilin 2 gene (PSEN2) and $\mathrm{A} \beta_{1-40}$ levels. However, some studies have reported an association of lower $A \beta_{1-42}$ in the presence of APOE $\varepsilon 4$ alleles $[10,28,38]$ and at least one study has described a lower $A \beta_{1-42} / A \beta_{1-40}$ ratio in nonAPOE $\varepsilon 4$ subjects in the highest tertile of physical activity [39]. A third study found increased $A \beta$ in young, nondemented first-degree relatives of late onset AD compared to unrelated controls [31]. Other factors associated with $\mathrm{A} \beta$ plasma levels are creatinine levels $[10,28,38,40]$, high density lipoproteins [27], body mass index [27], race [38] and sex [38,41]. One study included age, platelet count, total protein concentration and creatinine levels in a multivariate analysis and found that these variables accounted for $12.9 \%$ of plasma levels, underscoring the importance of using multivariable models that adjust for possible confounders [10]. Like CSF levels, plasma levels show a circadian fluctuation that decreases with aging [11]. Therefore, standardization of sampling time is important.

\section{Technical aspects regarding sample storage and $A \beta$ plasma} measurements

$\mathrm{A} \beta_{1-40}$ and $\mathrm{A} \beta_{1-42}$ are stable at 2 to $8^{\circ} \mathrm{C}$ for $6 \mathrm{~h}$ but when $\mathrm{A} \beta$ is kept at room temperature for $24 \mathrm{~h}$ levels drop considerably, exceeding a $20 \%$ loss in most of the pools [42-45], although ratios of different $A \beta$ species can be more stable [43]. Storage at $-20^{\circ} \mathrm{C}$ is not suitable for longterm storage and $\mathrm{A} \beta$ levels are not stable through freezethaw cycles following storage at $-20^{\circ} \mathrm{C}$, whereas storage at $-70^{\circ} \mathrm{C}$ shows no reductions in $\mathrm{A} \beta$ levels for up to three cycles and $A \beta$ levels are stable for at least 12 months when stored at this temperature $[42,45]$. One study has reported that some $A \beta$ peptides increase their concentration once frozen [46]. Repeated samples taken during fasting and in the post-prandial state and repeated samples taken from cognitively normal $(\mathrm{CN})$ subjects within three weeks show coefficients of variation (CV) 
that are within the range of the variability of the assay in both cases, indicating that these pre-analytical factors do not have an important effect on $A \beta$ measurements [13]. Although not formally tested in plasma, storage in polypropylene tubes currently is the best way to minimize adherence of $A \beta$ to the wall of storage vials compared to polystyrene for CSF samples [47], and is current practice for plasma samples. Different types of polypropylene are used in the manufacture of biofluid storage vials, but the effects of these differences on $A \beta$ levels following shortand long-term storage are not well documented. Finally, collection parameters like collected blood volume and time to freeze have been associated with levels of plasma $A \beta[48]$ and $A \beta$ levels in serum are also less stable than plasma $\mathrm{A} \beta$ levels [43].

\section{Association of $A \beta$ with $A D$ and cerebrovascular disease}

Cross-sectional and longitudinal results in DS individuals and subjects harboring autosomal dominant FAD mutations The initial study by Scheuner et al. described increased plasma levels of $A \beta_{1-42}$ in subjects from FAD kindreds with pathogenic mutations in the APP, PSEN1 and PSEN2 genes when compared to non-mutation bearing controls [49] and Kosaka et al. found increased plasma levels of $A \beta_{1-42}$ when comparing AD patients carrying the $\beta$ APP717 mutation to sporadic AD patients [50]. Recently, a cross-sectional cohort of asymptomatic carriers of the PSEN1 E280A mutation had higher $A \beta_{1-42}$ and $A \beta_{1-42}$ l $\mathrm{A} \beta_{1-40}$ than matched $\mathrm{CN}$ controls without the mutation [51].

DS subjects show higher plasma $A \beta_{1-42}$ and $A \beta_{1-40}$ levels than $\mathrm{CN}$ subjects without trisomy $21[34,52]$. Two studies found no differences comparing DS with and without dementia, although an association between $A \beta$ levels and neuropsychological scores in multivariable adjusted models was found [34,35]. In one of these studies demented DS (dDS) subjects with longer dementia duration showed higher $A \beta_{1-42}$, lower $A \beta_{1-40}$ and a higher $A \beta_{1-42} / A \beta_{1-40}$ ratio than those with shorter dementia duration [35]. Two other studies comparing dDS to cognitively normal DS (cnDS) found a higher $\mathrm{A} \beta_{1-42} /$ $\mathrm{A} \beta_{1-40}$ ratio in $\mathrm{dDS}$ [53] and increased $\mathrm{A} \beta_{1-40}$ levels in $\mathrm{dDS}$ subjects compared to cnDS that remained stable during a follow-up of several years [54]. Consecutive studies by Schupf et al. [32,52] have described increased $A \beta_{1-42}$ in $\mathrm{dDS}$ when compared to cnDS. These and other studies of plasma $A \beta$ levels in subjects with trisomy 21 and pathogenic FAD mutations are summarized in Table 1.

There are limited data from prospective studies of plasma $A \beta$ levels in subjects with DS (Table 2), but one study described an increased risk of dementia in subjects who at baseline had increased levels of $A \beta_{1-42}$ or $A \beta_{1-40}$ [54]. However, in studies conducted by another group, only baseline levels of $A \beta_{1-42}$ were associated with an increased risk of dementia and death [32]. Finally, in a third study, Schupf et al. [33] compared the measurements of the last and baseline visits, finding an increased risk of dementia with an increase in $A \beta_{1-40}$, a decrease in $A \beta_{1-42}$ or a decrease in $A \beta_{1-42} / A \beta_{1-40}$ ratio with repeated sampling during follow-up.

\section{Cross-sectional results in sporadic $A D$ cases}

Results differ between studies including $\mathrm{CN}$ and sporadic AD subjects (Table 3). Different associations have been reported, with increased levels of $A \beta_{1-42}$ in $A D$ patients [27], decreased levels of $A \beta_{1-42}$ in $\mathrm{AD}$ [14] and increased $\mathrm{A} \beta_{1-40}$ in $\mathrm{AD}$ [55]. Regarding the gender effect, one study found higher $A \beta_{1-42}$ levels in women with mild cognitive impairment (MCI) compared to $\mathrm{CN}$ women and $\mathrm{CN}$ and MCI male subjects [41].

Some studies classified subjects not only based on clinical diagnosis but also on AD-like CSF profiles for tau and $A \beta$ profiles $[10,13,56]$. In a study that included $C N$ and MCI subjects, the group of $\mathrm{CN}$ and MCI subjects with $A D$-like CSF tau and $A \beta$ profiles showed lower plasma $A \beta_{1-42} / A \beta_{1-40}$ than $C N$ and MCI subjects with normal CSF tau and A $\beta$ levels [13]. Another study found decreased $A \beta_{1-42}$ and $A \beta_{1-42} / A \beta_{1-40}$ in $M C I$ and $A D$ subjects with an $A D$-like CSF tau and $A \beta$ signature when compared to MCI and AD subjects with normal CSF tau and $A \beta$ levels [56]. A more complex association was found for plasma $A \beta_{1-40}$ and $A \beta_{1-42}$ levels in the $A D$ Neuroimaging Initiative (ADNI) cohort, showing an interaction between age and diagnostic groups defined by an $\mathrm{AD}$-like CSF tau and $\mathrm{A} \beta$ profile [10]. Based on these results, only younger $\mathrm{MCI}$ and $\mathrm{AD}$ subjects with an $\mathrm{AD}$ like CSF signature showed lower $A \beta_{1-40}$ and $A \beta_{1-42}$ values than older MCI and AD subjects with an AD-like CSF signature or subjects with a normal CSF signature. These findings indicate that the presence of AD-like CSF in younger cognitively impaired subjects was what defined the group with lower plasma $A \beta$. There were not enough $\mathrm{CN}$ subjects with AD-like CSF to test the association in this group of subjects who are in the pre-symptomatic stage of AD. Although most of these studies do not report sensitivity, specificity or area under the curve (AUC) measures for plasma $A \beta$ levels, it is clear from these publications that determination of plasma $A \beta$ levels is not useful as a diagnostic classifier.

\section{Longitudinal results in the $\mathrm{CN}$ population and $\mathrm{MCl}$ and sporadic AD cases}

Different measures of plasma $A \beta$ have been associated with progression to dementia (Table 4): high baseline $\mathrm{A} \beta_{1-42}[30,57]$, low baseline $A \beta_{1-42} / A \beta_{1-40}[58,59]$, low baseline $A \beta_{1-40}$ or $A \beta_{1-42}$ [60], high baseline $A \beta_{1-40}$ [29], high $A \beta_{1-40}$ or low $A \beta_{1-42} / A \beta_{1-40}[61]$ and low $A \beta_{1-40}$ in older 
Table 1. Cross-sectional studies in populations including Down syndrome and familial Alzheimer's disease due to trisomy 21 or autosomal dominant mutations, respectively

\begin{tabular}{|c|c|c|c|c|c|c|c|c|c|c|}
\hline \multirow[b]{2}{*}{ Study } & \multirow[b]{2}{*}{ Subjects } & \multirow{2}{*}{$\begin{array}{c}\text { Mean } \\
\text { age } \\
\text { (years) }\end{array}$} & \multirow{2}{*}{$\begin{array}{l}\text { Platform } \\
\text { and } \\
\text { antibodies }\end{array}$} & \multirow[b]{2}{*}{$\% \mathrm{CV}$} & \multicolumn{3}{|c|}{$\begin{array}{l}\text { Values in DS patients } \\
\text { compared to controls }\end{array}$} & \multicolumn{3}{|c|}{$\begin{array}{c}\text { Values in dDS } \\
\text { compared to cnDS }\end{array}$} \\
\hline & & & & & $A \beta_{1-40}$ & $A \beta_{1-42}$ & $\begin{array}{l}A \beta_{1-42} / \\
A \beta_{1-40}\end{array}$ & $A \beta_{1-40}$ & $A \beta_{1-42}$ & $\begin{array}{c}A \beta_{1-42} / \\
A \beta_{1-40}\end{array}$ \\
\hline Schupf et al. 2001 [52] & $\begin{array}{c}97 \mathrm{cnDS} \\
11 \mathrm{dDS}\end{array}$ & $\begin{array}{c}51.9 \\
56\end{array}$ & $\begin{array}{l}\text { ELISA } \\
\text { 6E10 } \\
\text { R182 } \\
\text { R165 }\end{array}$ & - & $\uparrow$ & $\uparrow$ & - & $=$ & $\uparrow$ & - \\
\hline Schupf et al. 2007 [32] & & & $\begin{array}{l}\text { ELISA } \\
6 \text { E10 } \\
\text { R182 } \\
\text { R165 }\end{array}$ & - & - & - & - & $=$ & $\uparrow$ & - \\
\hline Matsuoka et al. 2009 [53] & $\begin{array}{c}148 \mathrm{cnDS} \\
52 \mathrm{dDS}\end{array}$ & $\begin{array}{l}54.2 \\
56.0\end{array}$ & $\begin{array}{c}\text { ELISA } \\
82 \mathrm{E} 1 \\
1 \mathrm{~A} 10 \\
1 \mathrm{C} 3\end{array}$ & $<11.0 \%$ & - & - & - & $=$ & $=$ & $\uparrow$ \\
\hline Prasher et al. 2010 [35] & $\begin{array}{l}83 \mathrm{cnDS} \\
52 \mathrm{dDS}\end{array}$ & $\begin{array}{l}49.0 \\
56.8\end{array}$ & $\begin{array}{l}\text { ELISA } \\
6 \text { E10 } \\
\text { R182 } \\
\text { R165 }\end{array}$ & - & - & - & - & $=$ & $=$ & $={ }^{\mathrm{a}}$ \\
\hline Head et al. 2011 [34] & $\begin{array}{c}11 \mathrm{yCN} \\
12 \mathrm{aCN} \\
17 \mathrm{AD} \\
43 \mathrm{cnDS} \\
52 \mathrm{dDS}\end{array}$ & $\begin{array}{c}46.5 \\
74.2 \\
75.3 \\
45 \\
53.3\end{array}$ & $\begin{array}{l}\text { ELISA } \\
\text { Wako }\end{array}$ & - & $\uparrow$ & $\uparrow$ & $=$ & - & - & - \\
\hline Coppus et al. 2012 [54] & $\begin{array}{c}62 \mathrm{dDS} \\
264 \mathrm{cnDS}\end{array}$ & $\begin{array}{c}54 \\
50.6\end{array}$ & $\begin{array}{c}\text { XMAP } \\
\text { INNO-BIA }\end{array}$ & - & - & - & - & $\uparrow$ & $=$ & $=$ \\
\hline Reiman et al. 2012 [51] & $\begin{array}{l}10 \text { PSEN1 + CN } \\
10 \text { PSEN1-CN }\end{array}$ & $\begin{array}{l}23 \\
24\end{array}$ & $\begin{array}{c}\text { XMAP } \\
\text { INNO-BIA }\end{array}$ & - & - & - & - & - & - & - \\
\hline
\end{tabular}

${ }^{a} \mathrm{dDS}$ who had a dementia history of 4 or more years had increased $A \beta_{1-42} / A \beta_{1-40}$ compared with dDS with a more recent diagnosis. aCN, aged cognitively normal controls; AD, Alzheimer's disease; CN, cognitively normal; cnDS, cognitively normal Down syndrome; CV, coefficient of variation; dDS, demented Down syndrome; DS, Down syndrome; $\mathrm{YCN}$, young cognitively normal controls.

subjects [62]. Finally, other studies found no associations of plasma $A \beta$ levels with progression to dementia $[10,13,63]$. A study including information on vascular risk factors in midlife and a long follow-up period after baseline plasma sampling found an increased risk of dementia in subjects with low $A \beta_{1-40}$ and $A \beta_{1-42}$ at baseline and there was an interaction between plasma $A \beta$ levels and diastolic blood pressure that indicated a higher incidence of dementia in subjects with higher diastolic blood pressure and low plasma A $\beta$ levels [60]. One study that compared $\mathrm{A} \beta$ plasma levels in $\mathrm{CN}$ and $\mathrm{MCI}$ subjects who remained cognitively stable or progressed to $\mathrm{AD}$ found no differences in these two different cohorts [13], but, as noted above, there were significant differences based on the CSF-defined groups.

Other studies measuring plasma $A \beta$ levels included correlations of these values with cognitive measures instead of using a diagnosis as outcome. One study included 481 subjects with a long follow-up and repeated measurements, and it used repeated brief telephone interviews for determining the study outcome, and the authors reported greater cognitive decline in subjects with a low $A \beta_{1-42} / A \beta_{1-40}$ at baseline [64]. However, interassay CV was over $30 \%$ (repeated subject measurements were included in the same assay with $\mathrm{CV}<10 \%)$. A larger study of $997 \mathrm{CN}$ subjects followed for 9 years also found a faster cognitive decline in subjects with a lower $\mathrm{A} \beta_{1-42} /$ $\mathrm{A} \beta_{1-40}$ at baseline [65]. Cosentino et al. [66] followed 880 subjects for 4.5 years who were $\mathrm{CN}$ at baseline or had cognitive impairment that was not severe enough for a dementia diagnosis. In this study, subjects with higher baseline $A \beta_{1-40}$ and $A \beta_{1-42}$ and stable or decreasing $A \beta_{1-42}$ levels during follow-up had a faster rate of decline, whereas $A \beta_{1-42} / A \beta_{1-40}$ showed no such association. On the other hand, in another study by Locascio et al. [67], the rate of cognitive decline in $122 \mathrm{AD}$ patients was determined in subjects followed for 4.2 years, and these authors described a faster decline in subjects with lower 
Table 2. Longitudinal studies in populations including Down syndrome

\begin{tabular}{|c|c|c|c|c|c|c|c|}
\hline Study & Subjects & $\begin{array}{c}\text { Mean } \\
\text { age } \\
\text { (years) }\end{array}$ & $\begin{array}{l}\text { Follow-up } \\
\text { duration }\end{array}$ & $\begin{array}{l}\text { Platform } \\
\text { and } \\
\text { antibodies }\end{array}$ & CV & $\begin{array}{l}\text { Analyte associated } \\
\text { with conversion risk }\end{array}$ & Magnitude \\
\hline Schupf et al. 2007 [32] & $\begin{array}{l}44 \text { DSp } \\
130 \mathrm{cnDS}\end{array}$ & - & 5 years $^{\mathrm{a}}$ & $\begin{array}{l}\text { ELISA } \\
\text { 6E10 } \\
\text { R182 } \\
\text { R165 }\end{array}$ & - & $\uparrow$ baseline $A \beta_{1-42}$ & $\mathrm{HR}=2.6$ \\
\hline Schupf et al. 2010 [33] & $\begin{array}{l}61 \text { DSp } \\
164 \text { cnDS }\end{array}$ & $\begin{array}{l}53.7 \\
50.3\end{array}$ & - & $\begin{array}{l}\text { ELISA } \\
6 \text { E10 } \\
\text { R182 } \\
\text { R165 }\end{array}$ & - & $\begin{array}{c}\text { Decrease of } A \beta_{1-40} \\
\text { Stable } A \beta_{1-42} \\
\text { Decrease } A \beta_{1-42} \\
\text { Stable } A \beta_{1-42} / A \beta_{1-40} \\
\text { Decrease } A \beta_{1-42} / A \beta_{1-40}\end{array}$ & $\begin{array}{l}H R=0.4 \\
H R=2.6 \\
H R=4.9 \\
H R=3.9 \\
H R=4.9\end{array}$ \\
\hline Coppus et al. 2012 [54] & $\begin{array}{l}79 \mathrm{DSp} \\
264 \mathrm{cnDS}\end{array}$ & $\begin{array}{l}53.3 \\
50.6\end{array}$ & - & $\begin{array}{c}\text { XMAP } \\
\text { INNO-BIA }\end{array}$ & - & $\begin{array}{l}\uparrow \text { baseline } A \beta_{1-40} \\
\uparrow \text { baseline } A \beta_{1-42}\end{array}$ & $\begin{array}{l}H R=2.05 \\
H R=2.56\end{array}$ \\
\hline
\end{tabular}

${ }^{a}$ Estimated by author of review. cnDS, cognitively normal Down syndrome; CV, coefficient of variation; DSp, Down syndrome subjects who progress to a dementia diagnosis; HR, hazard ratio.

plasma $A \beta_{1-40}$ and $A \beta_{1-42}$ at baseline. Two studies found an interaction between cognitive reserve and $A \beta$ plasma levels, indicating that subjects with lower cognitive reserve showed a greater decline associated with $A \beta$ levels $[10,65]$.

\section{Longitudinal sampling of $A \beta$ plasma measures}

A small number of studies have included repeated sampling of plasma $A \beta$ levels $[10,27,29,57]$. In the study by Mayeux et al. [27], a general increase was found for plasma $A \beta_{1-40}$ over time, and plasma $A \beta_{1-40}$ levels in $C N$ stable subjects showed an increase over time, while incident and baseline AD subjects showed a decrease over time. A second study of the same group reported an increased incidence of dementia in $\mathrm{CN}$ subjects who showed a decrease in $A \beta_{1-42}$ and $A \beta_{1-42} / A \beta_{1-40}$ during follow-up [57]. The study of Okereke et al. [64] found that a decrease in $\mathrm{A} \beta_{1-42} / \mathrm{A} \beta_{1-40}$ in the repeated plasma measurement was associated with greater cognitive decline. Lastly, studies reported by Hansson et al. [29] and Toledo et al. [10] found that during follow-up of 324 subjects for 5 years in the former and 613 subjects for 2 to 3 years in the latter study, there was an increase of $\mathrm{A} \beta_{1-40}$ and $\mathrm{A} \beta_{1-42}$, whereas $\mathrm{A} \beta_{1-42} / \mathrm{A} \beta_{1-40}$ decreased.

\section{$A \beta$ plasma measures and cerebrovascular disease}

An association between plasma $A \beta_{1-40}$ and $A \beta_{1-42}$ levels in APOE $\varepsilon 4$ carriers and in subjects known to have lacunar infarcts and white matter hyperintensities has been described in the Rotterdam study [28]. A second study that included subjects with cerebral amyloid angiopathy, MCI and AD also found an association between increased $A \beta$ plasma and the presence of white matter hyperintensities and lacunar infarcts [68]. A third study specifically analyzed the association between microbleeds and plasma $\mathrm{A} \beta$ levels in subjects with $\mathrm{AD}$ and vascular dementia [69]. In this study, patients with nonlobar hemorrhages, located in the deep gray matter region and associated with hypertensive vasculopathy, showed higher $A \beta_{1-40}$ plasma levels compared to subjects with lobar hemorrhages, which are associated with cerebral amyloid angiopathy. In the ADNI cohort, we found no association between $\mathrm{A} \beta$ plasma levels and white matter hyperintensities, but subjects with infarcts on MRI had higher plasma $A \beta_{1-42}$ levels [10]. Finally, a longitudinal study by Lambert et al. [59] reported a higher incidence of vascular dementia in subjects with a low $A \beta_{1-42} / A \beta_{1-40}$.

\section{$A \beta$ plasma measures as biomarkers in clinical trials}

Repeated sampling and measurement of plasma A $\beta$ levels have been used to monitor the pharmacodynamic response of subjects in clinical trials of $\gamma$-secretase inhibitors (GSIs) and modulators (GSMs) as well as for passive immunotherapy. Studies in subjects treated with GSIs showed an initial dose-dependent decrease of total $A \beta$ and $A \beta_{1-40}$ levels that was followed by a dose-independent increase of both analytes [70,71]. A model based on a hypothetical inhibition of $\alpha$-secretase by increases in C99 associated with GSI treatment has been proposed in order to explain these changes, but this remains to be proven [72]. Both studies by Siemers et al. [70,71] did not report changes in CSF $A \beta_{1-40}$ and $A \beta_{1-42}$ levels, although the second sample was taken 4 hours after treatment and a longer timeframe might be needed to assess changes in the CSF levels of these A $\beta$ species. Due to the worse cognitive outcome and secondary effects (severe gastrointestinal toxicity, immunomodulation and skin cancer) in patients treated with GSIs [73], research in this area has shifted towards GSMs that spare Notch signaling. These GSM have also shown a decrease of plasma $A \beta$ [74-76] but the results regarding any $A \beta$-rebound are contradictory for GSMs $[75,76]$. On the other hand, 
Table 3. Cross-sectional studies in populations including sporadic Alzheimer's disease patients

\begin{tabular}{|c|c|c|c|c|c|c|c|c|}
\hline \multirow[b]{2}{*}{ Study } & \multirow[b]{2}{*}{ Subjects } & \multirow{2}{*}{$\begin{array}{c}\text { Mean } \\
\text { age } \\
\text { (years) }\end{array}$} & \multirow{2}{*}{$\begin{array}{l}\text { Platform } \\
\text { and } \\
\text { antibodies }\end{array}$} & \multirow[b]{2}{*}{ CV } & \multicolumn{3}{|c|}{ Values in $A D$ patients } & \multirow[b]{2}{*}{ Other } \\
\hline & & & & & $A \beta_{1-40}$ & $A \beta_{1-42}$ & $\begin{array}{l}A \beta_{1-42} / \\
A \beta_{1-40}\end{array}$ & \\
\hline Mehta et al. 2000 [55] & $\begin{array}{l}61 C N \\
78 \mathrm{AD}\end{array}$ & $\begin{array}{l}67 \\
74\end{array}$ & $\begin{array}{l}\text { ELISA } \\
6 \text { E10 } \\
\text { R162 } \\
\text { R164 }\end{array}$ & $<18 \%$ & $\uparrow$ & $=$ & - & \\
\hline Mayeux et al. 2003 [27] & $\begin{array}{l}79 \mathrm{AD} \\
365 \mathrm{CN}\end{array}$ & $\begin{array}{l}83.2 \\
75.5\end{array}$ & $\begin{array}{l}\text { ELISA } \\
\text { 6E10 } \\
\text { R182 } \\
\text { R165 }\end{array}$ & - & $=$ & $\uparrow$ & NA & \\
\hline $\begin{array}{l}\text { Fukumoto et al. } \\
2003[26]\end{array}$ & $\begin{array}{l}92 \mathrm{CN} \\
96 \mathrm{PD} \\
37 \mathrm{MCl} \\
146 \mathrm{AD}\end{array}$ & $\begin{array}{c}69 \\
66.0 \\
72.6 \\
76\end{array}$ & $\begin{array}{l}\text { ELISA } \\
\text { Takeda }\end{array}$ & $<10 \%$ & $=$ & $=$ & $=$ & \\
\hline Assini et al. 2004 [41] & $\begin{array}{l}72 \mathrm{CN} \\
88 \mathrm{MCl}\end{array}$ & $\begin{array}{l}73 \\
75\end{array}$ & $\begin{array}{l}\text { ELISA } \\
\text { IBL }\end{array}$ & - & - & - & - & Increased $A \beta_{1-42}$ in $\mathrm{MCl}$ women \\
\hline $\begin{array}{l}\text { Lewczuk et al. } \\
2010[56]\end{array}$ & $\begin{array}{c}137 \mathrm{MClp} \\
62 \mathrm{MCl}-\mathrm{OD} \\
127 \mathrm{AD} \\
25 \mathrm{OD}\end{array}$ & $\begin{array}{l}67.4 \\
63.3 \\
70.8 \\
66.6\end{array}$ & $\begin{array}{l}\text { XMAP } \\
\text { INNO-BIA }\end{array}$ & $<10 \%$ & - & - & - & $\begin{array}{l}\mathrm{MCl} \text { and } \mathrm{AD} \text { with } \mathrm{AD} \text {-like CSF } \\
\quad \downarrow \mathrm{A} \beta_{1-42} \& \downarrow \mathrm{A} \beta_{1-421} A \beta_{1-40}\end{array}$ \\
\hline Lui et al. 2010 [14] & $\begin{array}{l}724 \mathrm{CN} \\
122 \mathrm{MCl} \\
186 \mathrm{AD}\end{array}$ & $\begin{array}{l}70.0 \\
75.9 \\
78.6\end{array}$ & $\begin{array}{c}\text { ELISA } \\
\text { Mehta } \\
\text { XMAP } \\
\text { INNO-BIA }\end{array}$ & - & $=$ & $\downarrow$ & $=$ & \\
\hline $\begin{array}{l}\text { Le Bastard et al. } \\
2010 \text { [12] }\end{array}$ & $\begin{array}{c}47 \mathrm{CN} \\
50 \text { non-AD } \\
47 \mathrm{AD}\end{array}$ & $\begin{array}{l}69 \\
74 \\
82\end{array}$ & $\begin{array}{c}\text { XMAP } \\
\text { INNO-BIA }\end{array}$ & $<10 \%$ & $=$ & $=$ & $=$ & $\downarrow A \beta_{1-42} / A \beta_{N-42}$ \\
\hline $\begin{array}{l}\text { Toledo et al. } 2011 \text { [10], } \\
\text { Figurski et al. } 2012 \text { [48] }\end{array}$ & $\begin{array}{c}187 \mathrm{CNs} \\
10 \mathrm{CNp} \\
162 \mathrm{MCls} \\
145 \mathrm{MClp} \\
162 \mathrm{AD}\end{array}$ & $\begin{array}{l}75.8 \\
78.4 \\
74.7 \\
74.6 \\
75.3\end{array}$ & $\begin{array}{l}\text { XMAP } \\
\text { INNO-BIA }\end{array}$ & $<10 \%$ & $=$ & $=$ & $=$ & $\begin{array}{l}\text { Interaction between age and } \\
\text { diagnosis defined by CSF }\end{array}$ \\
\hline
\end{tabular}

$\mathrm{AD}$, Alzheimer's disease; $\mathrm{CN}$, cognitively normal; $\mathrm{CNp}$, cognitively normal progression; CNs, cognitive normal stable; $\mathrm{CV}$, coefficient of variation; $\mathrm{MCl}$, mild cognitive impairment; $M C I-O D$, mild cognitive impairment, progression to non-AD dementia; $M C l p$, mild cognitive impairment progressor (to AD); $M C l s$, mild cognitive impairment stable; NA, not available; OD, other dementia; PD, Parkinson's disease.

passive immunotherapy results from clinical trials suggest that there is a dose-dependent transient increase of plasma $A \beta$ in response to the monoclonal anti-A $\beta$ antibody infusion and this was reported to last several weeks [77]. Thus, more research is clearly needed to elucidate the effects of these disease-modifying therapies on plasma $A \beta$ levels.

\section{Conclusions}

Plasma $A \beta$ is well known to originate in different organs and it also is known that $A \beta$ binds to different proteins and cells in the blood, thereby possibly accounting for why plasma $A \beta$ levels do not correlate with $A \beta$ measured in CSF or CNS plaque burden measured by PET amyloid plaque imaging. Levels of plasma $A \beta$ increase with aging and some clinical associations may change depending on the age of the selected sample. The selection of capture antibodies and analytical platforms can have an important impact on the measured $A \beta$ levels; a wide range of mean $\mathrm{A} \beta_{1-40}$ (214 [15] to $985 \mathrm{pg} / \mathrm{ml}$ [40]) and $\mathrm{A} \beta_{1-42}$ (36 [15] to $140 \mathrm{pg} / \mathrm{ml}$ [19]) levels in $\mathrm{AD}$ patients has been reported in different studies and this also is the case for studies of $\mathrm{CN}$ subjects. Moreover, even in studies that use the same analytical platform and capture antibodies, there are important differences in the measured $A \beta$ levels, which could be attributed to pre-analytical and analytical factors $[10,42-44,48]$. A recent study showed that automating multiple pipetting steps in a commercially available immunoassay that measures $A \beta_{1-42}$ and $\mathrm{A} \beta_{1-40}$ provided better precision, thus leading to standardization of reagent dispensing in this test system [48]. Therefore, standardization efforts such as this and 
Table 4. Longitudinal studies in populations including sporadic Alzheimer's disease patients

\begin{tabular}{|c|c|c|c|c|c|c|c|}
\hline Study & Subjects & $\begin{array}{l}\text { Mean } \\
\text { age at } \\
\text { baseline } \\
\text { (years) }\end{array}$ & $\begin{array}{l}\text { Duration } \\
\text { of } \\
\text { follow-up } \\
\text { (years) }\end{array}$ & $\begin{array}{l}\text { Platform } \\
\text { and } \\
\text { antibodies }\end{array}$ & CV & $\begin{array}{l}\text { Analyte associated } \\
\text { with increased } \\
\text { risk conversion } \\
\text { to } A D\end{array}$ & Magnitude \\
\hline Mayeux et al. 1999 [30] & $\begin{array}{l}105 \mathrm{CNs} \\
64 \mathrm{CNp}\end{array}$ & $\begin{array}{l}73.4 \\
77.4\end{array}$ & 3.5 & $\begin{array}{l}\text { ELISA } \\
6 \text { E10 } \\
\text { R182 } \\
\text { R165 }\end{array}$ & - & High baseline $A \beta_{1-42}$ & $\mathrm{HR}=3.6-4.0$ \\
\hline Mayeux et al. 2003 [27] & $\begin{array}{l}365 \mathrm{CNs} \\
86 \mathrm{CNp}\end{array}$ & $\begin{array}{l}75.5 \\
79.3\end{array}$ & & $\begin{array}{l}\text { ELISA } \\
6 \text { E10 } \\
\text { R182 } \\
\text { R165 }\end{array}$ & - & High baseline $A \beta_{1-42}$ & $1.9-2.4$ \\
\hline van Oijen et al. 2006 [61] & $\begin{array}{c}1364 \mathrm{CNs} \\
289 \mathrm{CNp} \\
103 \mathrm{CNp}-\mathrm{OD}\end{array}$ & & 8.5 & $\begin{array}{l}\text { ELISA } \\
6 \text { E10 } \\
\text { R226 } \\
\text { R209 }\end{array}$ & $<15 \%$ & $\begin{array}{l}\text { High baseline } A \beta_{1-40} \\
\text { Low baseline } A \beta_{1-42} / A \beta_{1-40}\end{array}$ & $\begin{array}{l}H R=1.17 \\
H R=1.82\end{array}$ \\
\hline Graff-Radford et al. 2007 [58] & $\begin{array}{l}510 \mathrm{CNs} \\
53 \mathrm{CNp}\end{array}$ & - & 5 & $\begin{array}{l}\text { ELISA } \\
\text { BAN-50 } \\
\text { BA27 } \\
\text { BC05 }\end{array}$ & - & Low baseline $A \beta_{1-42} / A \beta_{1-40}$ & $R R=2.47-3.08$ \\
\hline Lopez et al. 2008 [63] & $\begin{array}{l}117 \mathrm{CNs} \\
115 \mathrm{CNp} \\
9 \mathrm{MCls} \\
33 \mathrm{MClp}\end{array}$ & $\begin{array}{l}78.6 \\
79.9 \\
80.5 \\
79.6\end{array}$ & 4.5 & ELISA & - & None & - \\
\hline Sundelöf et al. 2008 [62] & $\begin{array}{l}608 \mathrm{CNs} \\
74 \mathrm{CNp}\end{array}$ & - & 11.2 & $\begin{array}{l}\text { ELISA } \\
\text { BNT77 } \\
\text { BA27 } \\
\text { BC05 }\end{array}$ & - & $\begin{array}{l}\text { Low baseline } A \beta_{1-40} \\
\text { (only in the cohort older } \\
\text { than } 77 \text { at baseline) }\end{array}$ & $\mathrm{HR}=4.9$ \\
\hline Schupf 2008 [57] & $\begin{array}{l}104 \mathrm{MClp} \\
1021 \mathrm{CNs}\end{array}$ & $\begin{array}{l}80.7 \\
76.3\end{array}$ & 4.5 & $\begin{array}{l}\text { ELISA } \\
6 \text { E10 } \\
\text { R182 } \\
\text { R165 }\end{array}$ & - & $\begin{array}{c}\text { High baseline } A \beta_{1-42} \\
\text { Decrease of } A \beta_{1-42} \\
\text { Decrease of } A \beta_{1-42} A \beta_{1-40}\end{array}$ & $\begin{aligned} H R & =2.3-3.5 \\
H R & =2.6 \\
H R & =3.4\end{aligned}$ \\
\hline Lambert et al. 2009 [59] & $\begin{array}{l}985 \mathrm{CNs} \\
233 \mathrm{CNp}\end{array}$ & $\begin{array}{l}73.8 \\
77.9\end{array}$ & 4 & $\begin{array}{c}\text { XMAP } \\
\text { INNO-BIA }\end{array}$ & - & Low baseline $A \beta_{1-42} / A \beta_{1-40}$ & $H R=2.0$ \\
\hline Blasko et al. 2010 [78] & $\begin{array}{l}122 \mathrm{CNs} \\
33 \mathrm{CNp}\end{array}$ & - & 5 & $\begin{array}{l}\text { ELISA } \\
\text { INNOTEST }\end{array}$ & $<17 \%$ & High baseline $A \beta_{1-42}$ & $\mathrm{OR}=1.7$ \\
\hline Hansson et al. 2010 [13] & & & & $\begin{array}{c}\text { XMAP } \\
\text { INNO-BIA }\end{array}$ & $<10 \%$ & No differences & \\
\hline Toledo et al. 2011 [10] & $\begin{array}{l}162 \mathrm{MCls} \\
145 \mathrm{MClp}\end{array}$ & $\begin{array}{l}74.7 \\
74.6\end{array}$ & 3.0 & $\begin{array}{c}\text { XMAP } \\
\text { INNO-BIA }\end{array}$ & $<10 \%$ & None & \\
\hline Shah et al. 2012 [60] & $\begin{array}{c}590 \mathrm{CNs} \\
53 \mathrm{MClp} \\
24 \mathrm{MClp}-\mathrm{VaD}\end{array}$ & - & 15.8 & $\begin{array}{l}\text { ELISA } \\
2 \mathrm{G} 3 \\
21 \mathrm{~F} 12\end{array}$ & $<20 \%$ & $\begin{array}{l}\text { Low baseline } A \beta_{1-40} \\
\text { Low baseline } A \beta_{1-42}\end{array}$ & $\begin{array}{l}H R=2.1 \\
H R=1.6\end{array}$ \\
\hline Hansson et al. 2012 [29] & $\begin{array}{c}677 \mathrm{CNs} \\
37 \mathrm{MClp} \\
11 \mathrm{MClp}-\mathrm{VaD} \\
5 \mathrm{MClp}-\mathrm{OD}\end{array}$ & $\begin{array}{l}73.1 \\
77.3 \\
78.9 \\
78.8\end{array}$ & 5 & $\begin{array}{c}\text { XMAP } \\
\text { INNO-BIA }\end{array}$ & $<10 \%$ & High baseline $A \beta_{1-40}$ & $\mathrm{OR}=2.2$ \\
\hline
\end{tabular}

$A D$, Alzheimer's disease; $C N$ s, cognitively normal stable; $C N p$, cognitively normal progression; $C N p-O D$, cognitively normal progression to non- $A D$ dementia; $C S F$, cerebrospinal fluid; $\mathrm{HR}$, hazard ratio; $\mathrm{MClp}-\mathrm{OD}$, mild cognitive impairment, progression to non- $\mathrm{AD}$ dementia; $\mathrm{MClp}$, mild cognitive impairment progressor (to $\mathrm{AD}$ ); $M C l p-V a D$, mild cognitive impairment, progression to vascular dementia; $M C l s$, mild cognitive impairment stable; $\mathrm{OD}$, other dementia; $\mathrm{OR}$, odds ratio; $\mathrm{RR}$, relative risk. 
similar to the ones undertaken in the field of CSF A $\beta$ measurements are needed [47]. Thus, this variability precludes the possibility of establishing diagnostic or prognostic cut-offs across different studies and populations until these assays are better standardized.

Using the profile of CSF tau and A $\beta$ levels to define groups that have an underlying $\mathrm{AD}$ pathology reveals associations between subjects with and without AD-like CSF irrespective of a clinical diagnosis of $\mathrm{CN}, \mathrm{MCI}$ or $\mathrm{AD}$. Clinical diagnosis in the absence of a neuropathological validation or a CSF $A \beta$ levels/PET plaque load validation may underestimate and confound the diagnostic/prognostic value of plasma $A \beta$ measurements [2]. Cerebrovascular disease, which is a frequent finding in aged populations, is another important factor that can affect plasma $A \beta$ levels and the prevalence of vascular risk factor and vascular disease varies considerably in the different samples according to the design of the study. While not useful as a diagnostic biomarker as shown by the cross-sectional studies, repeated $A \beta$ plasma measurements in the same individual over time could become useful as a prognostic biomarker. Longitudinal studies favor the 'peripheral sink' hypothesis with a decrease of plasma levels starting in the dementia stage in contrast to an increase of plasma $A \beta$ during the pre-symptomatic stage so that disease stage-specific changes later in the course of AD may explain previously described conflicting results. Although the reported differences or changes in $A \beta$ plasma levels might not be large enough to predict the longitudinal outcome, it is potentially possible that this biomarker can serve as a prognostic factor or as an endpoint during follow-up of AD patients. However, prospective studies of cohorts with subsequent neuropathology confirmation of their diagnosis or in concert with data on CSF tau and A $\beta$ levels as well as other biomarker data are needed to establish how to best interpret data on plasma $A \beta$ levels in $C N, M C I$ and $A D$ subjects with and without other comorbid conditions such as cerebrovascular disease.

This article is part of a series on Peripheral Biomarkers, edited by Douglas Galasko. Other articles in this series can be found at http://alzres.com/series/biomarkers

\section{Abbreviations}

$A \beta$, amyloid beta; $A D$, Alzheimer's disease; ADNI, Alzheimer's Disease Neuroimaging Initiative; $A P O E$, apolipoprotein $E ; A P P, A \beta$ precursor protein: AV-45, florbetapir-F18; CN, cognitively normal; cnDS, cognitively normal Down syndrome; CNS, central nervous system; CSF, cerebrospinal fluid; CV, coefficient of variation; dDS, demented Down syndrome; DS, Down syndrome; ELISA, enzyme-linked immunosorbent assay; FAD, familial Alzheimer's disease; GSI, ү-secretase inhibitor; GSM, y-secretase modulator; $\mathrm{MCl}$, mild cognitive impairment; PET, positron emission tomography; PiB, Pittsburgh Compound-B-C11;

\section{Competing interests}

The authors declare that they have no competing interests.

\section{Acknowledgements}

The studies reviewed here from Penn were supported in part by AD10124. JQT is the William Maul Measey-Truman G Schnabel Jr Professor of Geriatric Medicine and Gerontology and JBT is supported in part by a grant of the Alfonso Martín Escudero Foundation.

Published: 8 March 2013

\section{References}

1. Montine TJ, Phelps CH, Beach TG, Bigio EH, Cairns NJ, Dickson DW, Duyckaerts C, Frosch MP, Masliah E, Mirra SS, Nelson PT, Schneider JA, Thal DR, Trojanowski JQ, Vinters HV, Hyman BT; National Institute on Aging; Alzheimer's Association: National Institute on Aging-Alzheimer's Association guidelines for the neuropathologic assessment of Alzheimer's disease: a practical approach. Acta Neuropathol 2012, 123:1-11.

2. Toledo JB, Brettschneider J, Grossman M, Arnold SE, Hu WT, Xie SX, Lee VM, Shaw LM, Trojanowski JQ: CSF biomarkers cutoffs: the importance of coincident neuropathological diseases. Acta Neuropathol 2012, 124:23-35.

3. Clark CM, Schneider JA, Bedell BJ, Beach TG, Bilker WB, Mintun MA, Pontecorvo MJ, Hefti F, Carpenter AP, Flitter ML, Krautkramer MJ, Kung HF, Coleman RE, Doraiswamy PM, Fleisher AS, Sabbagh MN, Sadowsky CH, Reiman EP, Zehntner SP, Skovronsky DM; AV45-A07 Study Group: Use of florbetapir-PET for imaging beta-amyloid pathology. JAMA 2011, 305:275-283.

4. Wolk DA, Zhang Z, Boudhar S, Clark CM, Pontecorvo MJ, Arnold SE: Amyloid imaging in Alzheimer's disease: comparison of florbetapir and Pittsburgh compound-B positron emission tomography. J Neurol Neurosurg Psychiatry 2012, 83:923-926.

5. Rissman RA, Trojanowski JQ, Shaw LM, Aisen PS: Longitudinal plasma amyloid beta as a biomarker of Alzheimer's disease. J Neural Transm 2012, 119:843-850.

6. Arai H, Lee VM, Otvos L, Jr., Greenberg BD, Lowery DE, Sharma SK, Schmidt $M L$, Trojanowski JQ: Defined neurofilament, tau, and beta-amyloid precursor protein epitopes distinguish Alzheimer from non-Alzheimer senile plaques. Proc Natl Acad Sci U S A 1990, 87:2249-2253.

7. Sinha S, Anderson JP, Barbour R, Basi GS, Caccavello R, Davis D, Doan M, Dovey HF, Frigon N, Hong J, Jacobson-Croak K, Jewett N, Keim P, Knops J, Lieberburg I, Power M, Tan H, Tatsuno G, Tung J, Schenk D, Seubert P, Suomensaari SM, Wang S, Walker D, Zhao J, McConlogue L, John V: Purification and cloning of amyloid precursor protein beta-secretase from human brain. Nature 1999, 402:537-540.

8. Mawuenyega KG, Sigurdson W, Ovod V, Munsell L, Kasten T, Morris JC, Yarasheski KE, Bateman RJ: Decreased clearance of CNS beta-amyloid in Alzheimer's disease. Science 2010, 330:1774.

9. Castellano JM, Kim J, Stewart FR, Jiang H, DeMattos RB, Patterson BW, Fagan AM, Morris JC, Mawuenyega KG, Cruchaga C, Goate AM, Bales KR, Paul SM, Bateman RJ, Holtzman DM: Human apoE isoforms differentially regulate brain amyloid-beta peptide clearance. Sci Trans/ Med 2011, 3:89ra57.

10. Toledo JB, Vanderstichele H, Figurski M, Aisen PS, Petersen RC, Weiner MW, Jack CR Jr, Jagust W, Decarli C, Toga AW, Toledo E, Xie SX, Lee VM, Trojanowski $J \mathrm{Q}$, Shaw LM; Alzheimer's Disease Neuroimaging Initiative: Factors affecting Abeta plasma levels and their utility as biomarkers in ADNI. Acta Neuropathol 2011, 122:401-413.

11. Huang Y, Potter R, Sigurdson W, Kasten T, Connors R, Morris JC, Benzinger T, Mintun M, Ashwood T, Ferm M, Budd SL, Bateman RJ: beta-Amyloid dynamics in human plasma. Arch Neurol 2012, 69:1591-1597.

12. Le Bastard N, Aerts L, Leurs J, Blomme W, De Deyn PP, Engelborghs S: No correlation between time-linked plasma and CSF Abeta levels. Neurochem Int 2009, 55:820-825.

13. Hansson O, Zetterberg $H$, Vanmechelen $E$, Vanderstichele $H$, Andreasson $U$, Londos E, Wallin A, Minthon L, Blennow K: Evaluation of plasma Abeta(40) and Abeta(42) as predictors of conversion to Alzheimer's disease in patients with mild cognitive impairment. Neurobiol Aging 2010, 31:357-367.

14. Lui JK, Laws SM, Li QX, Villemagne VL, Ames D, Brown B, Bush Al, De Ruyck K, Dromey J, Ellis KA, Faux NG, Foster J, Fowler C, Gupta V, Hudson P, Laughton K, Masters CL, Pertile K, Rembach A, Rimajova M, Rodriques M, Rowe CC, Rumble R, Szoeke C, Taddei K, Taddei T, Trounson B, Ward V, Martins RN, AIBL Research Group: Plasma amyloid-beta as a biomarker in Alzheimer's disease: the AIBL study of aging. J Alzheimers Dis 2010, 20:1233-1242.

15. Fagan AM, Mintun MA, Shah AR, Aldea P, Roe CM, Mach RH, Marcus D, Morris $J C$, Holtzman DM: Cerebrospinal fluid tau and ptau(181) increase with 
cortical amyloid deposition in cognitively normal individuals: implications for future clinical trials of Alzheimer's disease. EMBO Mol Med 2009, 1:371-380.

16. Weigand SD, Vemuri P, Wiste HJ, Senjem ML, Pankratz VS, Aisen PS, Weiner MW, Petersen RC, Shaw LM, Trojanowski JQ, Knopman DS, Jack CR Jr; Alzheimer's Disease Neuroimaging Initiative: Transforming cerebrospinal fluid Abeta42 measures into calculated Pittsburgh Compound B units of brain Abeta amyloid. Alzheimers Dement 2011, 7:133-141.

17. Devanand DP, Schupf N, Stern Y, Parsey R, Pelton GH, Mehta P, Mayeux R: Plasma Abeta and PET PiB binding are inversely related in mild cognitive impairment. Neurology 2011, 77:125-131.

18. Selkoe DJ, Podlisny MB, Joachim CL, Vickers EA, Lee G, Fritz LC, OltersdorfT: Beta-amyloid precursor protein of Alzheimer disease occurs as 110- to 135-kilodalton membrane-associated proteins in neural and nonneural tissues. Proc Natl Acad Sci U S A 1988, 85:7341-7345.

19. Roher AE, Esh CL, Kokjohn TA, Castaño EM, Van Vickle GD, Kalback WM, Patton RL, Luehrs DC, Daugs ID, Kuo YM, Emmerling MR, Soares H, Quinn JF, Kaye J, Connor DJ, Silverberg NB, Adler CH, Seward JD, Beach TG, Sabbagh MN: Amyloid beta peptides in human plasma and tissues and their significance for Alzheimer's disease. Alzheimers Dement 2009, 5:18-29.

20. Arai $H$, Lee VM, Messinger ML, Greenberg BD, Lowery DE, Trojanowski JQ: Expression patterns of beta-amyloid precursor protein (beta-APP) in neural and nonneural human tissues from Alzheimer's disease and control subjects. Ann Neurol 1991, 30:686-693.

21. Kuo YM, Kokjohn TA, Kalback W, Luehrs D, Galasko DR, Chevallier N, Koo EH, Emmerling MR, Roher AE: Amyloid-beta peptides interact with plasma proteins and erythrocytes: implications for their quantitation in plasma. Biochem Biophys Res Commun 2000, 268:750-756.

22. Skovronsky DM, Lee VM, Pratico D: Amyloid precursor protein and amyloid beta peptide in human platelets. Role of cyclooxygenase and protein kinase C. J Bio/ Chem 2001, 276:17036-17043.

23. Pesini P, Perez-Grijalba V, Monleon I, Boada M, Tarraga L, Martinez-Lage P, San-Jose I, Sarasa M: Reliable measurements of the beta-amyloid pool in blood could help in the early diagnosis of AD. Int J Alzheimers Dis 2012, 2012:604141.

24. Ghiso J, Shayo M, Calero M, Ng D, Tomidokoro Y, Gandy S, Rostagno A, Frangione B: Systemic catabolism of Alzheimer's Abeta40 and Abeta42. J Biol Chem 2004, 279:45897-45908.

25. Ghiso J, Calero M, Matsubara E, Governale S, Chuba J, Beavis R, Wisniewski T, Frangione B: Alzheimer's soluble amyloid beta is a normal component of human urine. FEBS Lett 1997, 408:105-108.

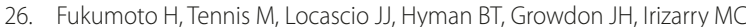
Age but not diagnosis is the main predictor of plasma amyloid betaprotein levels. Arch Neurol 2003, 60:958-964.

27. Mayeux R, Honig LS, Tang MX, Manly J, Stern Y, Schupf N, Mehta PD: Plasma A[beta]40 and A[beta]42 and Alzheimer's disease: relation to age, mortality, and risk. Neurology 2003, 61:1185-1190.

28. van Dijk EJ, Prins ND, Vermeer SE, Hofman A, van Duijn CM, Koudstaal PJ, Breteler MM: Plasma amyloid beta, apolipoprotein E, lacunar infarcts, and white matter lesions. Ann Neurol 2004, 55:570-575.

29. Hansson O, Stomrud E, Vanmechelen E, Ostling S, Gustafson DR, Zetterberg $\mathrm{H}$, Blennow K, Skoog I: Evaluation of plasma Abeta as predictor of Alzheimer's disease in older individuals without dementia: a populationbased study. J Alzheimers Dis 2012, 28:231-238.

30. Mayeux R, Tang MX, Jacobs DM, Manly J, Bell K, Merchant C, Small SA, Stern Y, Wisniewski HM, Mehta PD: Plasma amyloid beta-peptide 1-42 and incipient Alzheimer's disease. Ann Neurol 1999, 46:412-416.

31. Ertekin-Taner N, Younkin LH, Yager DM, Parfitt F, Baker MC, Asthana S, Hutton ML, Younkin SG, Graff-Radford NR: Plasma amyloid beta protein is elevated in late-onset Alzheimer disease families. Neurology 2008, 70:596-606.

32. Schupf N, Patel B, Pang D, Zigman WB, Silverman W, Mehta PD, Mayeux R: Elevated plasma beta-amyloid peptide Abeta(42) levels, incident dementia, and mortality in Down syndrome. Arch Neurol 2007, 64:1007-1013.

33. Schupf N, Zigman WB, Tang MX, Pang D, Mayeux R, Mehta P, Silverman W: Change in plasma Ass peptides and onset of dementia in adults with Down syndrome. Neurology 2010, 75:1639-1644

34. Head E, Doran E, Nistor M, Hill M, Schmitt FA, Haier RJ, Lott IT: Plasma amyloid-beta as a function of age, level of intellectual disability, and presence of dementia in Down syndrome. J Alzheimers Dis 2011, 23:399-409.
35. Prasher VP, Sajith SG, Mehta P, Zigman WB, Schupf N: Plasma beta-amyloid and duration of Alzheimer's disease in adults with Down syndrome. Int $J$ Geriatric Psychiatry 2010, 25:202-207.

36. Ertekin-Taner N, Graff-Radford N, Younkin LH, Eckman C, Adamson J, Schaid DJ, Blangero J, Hutton M, Younkin SG: Heritability of plasma amyloid beta in typical late-onset Alzheimer's disease pedigrees. Genet Epidemiol 2001, 21:19-30.

37. Ibrahim-Verbaas CA, Zorkoltseva IV, Amin N, Schuur M, Coppus AM, Isaacs A, Aulchenko YS, Breteler MM, Ikram MA, Axenovich TI, Verbeek MM, van Swieten JC, Oostra BA, van Duijn CM: Linkage analysis for plasma amyloid beta levels in persons with hypertension implicates Abeta-40 levels to presenilin 2. Hum Genet 2012, 131:1869-1876.

38. Metti AL, Cauley JA, Ayonayon HN, Harris TB, Rosano C, Williamson JD, Yaffe K: The demographic and medical correlates of plasma Abeta40 and Abeta42. Alzheimer Dis Assoc Disord 2012 [Epub ahead of print].

39. Brown BM, Peiffer JJ, Taddei K, Lui JK, Laws SM, Gupta VB, Taddei T, Ward VK, Rodrigues MA, Burnham S, Rainey-Smith SR, Villemagne VL, Bush A, Ellis KA, Masters CL, Ames D, Macaulay SL, Szoeke C, Rowe CC, Martins RN: Physical activity and amyloid-beta plasma and brain levels: results from the Australian Imaging, Biomarkers and Lifestyle Study of Ageing. Mol Psychiatry 2012 [Epub ahead of print].

40. Arvanitakis Z, Lucas JA, Younkin LH, Younkin SG, Graff-Radford NR: Serum creatinine levels correlate with plasma amyloid Beta protein. Alzheimer Dis Assoc Disord 2002, 16:187-190.

41. Assini A, Cammarata S, Vitali A, Colucci M, Giliberto L, Borghi R, Inglese ML, Volpe S, Ratto S, Dagna-Bricarelli F, Baldo C, Argusti A, Odetti P, Piccini A, Tabaton M: Plasma levels of amyloid beta-protein 42 are increased in women with mild cognitive impairment. Neurology 2004, 63:828-831.

42. Lachno DR, Emerson JK, Vanderstichele H, Gonzales C, Martenyi F, Konrad RJ Talbot JA, Lowe SL, Oefinger PE, Dean RA: Validation of a multiplex assay for simultaneous quantification of amyloid-beta peptide species in human plasma with utility for measurements in studies of Alzheimer's disease therapeutics. J Alzheimers Dis 2012, 32:905-918.

43. Bibl M, Welge V, Esselmann H, Wiltfang J: Stability of amyloid-beta peptides in plasma and serum. Electrophoresis 2012, 33:445-450.

44. Lachno DR, Evert BA, Vanderstichele H, Robertson M, Demattos RB, Konrad RJ, Talbot JA, Racke MM, Dean RA: Validation of assays for measurement of amyloid-beta peptides in cerebrospinal flui and plasma specimens from patients with Alzheimer's disease treated with solanezumab. J Alzheimers Dis 2013 [Epub ahead of print].

45. Le Bastard N, Leurs J, Blomme W, De Deyn PP, Engelborghs S: Plasma amyloid-beta forms in Alzheimer's disease and non-Alzheimer's disease patients. J Alzheimers Dis 2010, 21:291-301.

46. Lewczuk P, Esselmann H, Bibl M, Paul S, Svitek J, Miertschischk J, Meyrer R, Smirnov A, Maler JM, Klein C, Otto M, Bleich S, Sperling W, Kornhuber J, Rüther E, Wiltfang J: Electrophoretic separation of amyloid beta peptides in plasma. Electrophoresis 2004, 25:3336-3343.

47. Vanderstichele H, Bibl M, Engelborghs S, Le Bastard N, Lewczuk P, Molinuevo UL, Parnetti L, Perret-Liaudet A, Shaw LM, Teunissen C, Wouters D, Blennow K. Standardization of preanalytical aspects of cerebrospinal fluid biomarker testing for Alzheimer's disease diagnosis: a consensus paper from the Alzheimer's Biomarkers Standardization Initiative. Alzheimers Dement 2012 8:65-73

48. Figurski MJ, Waligorska T, Toledo J, Vanderstichele H, Korecka M, Lee VM, Trojanowski JQ, Shaw LM: Improved protocol for measurement of plasma beta-amyloid in longitudinal evaluation of Alzheimer's Disease Neuroimaging Initiative study patients. Alzheimers Dement 2012, 8:250-260.

49. Scheuner D, Eckman C, Jensen M, Song X, Citron M, Suzuki N, Bird TD, Hardy J, Hutton M, Kukull W, Larson E, Levy-Lahad E, Viitanen M, Peskind E, Poorkaj P, Schellenberg G, Tanzi R, Wasco W, Lannfelt L, Selkoe D, Younkin S: Secreted amyloid beta-protein similar to that in the senile plaques of Alzheimer's disease is increased in vivo by the presenilin 1 and 2 and APP mutations linked to familial Alzheimer's disease. Nat Med 1996, 2:864-870.

50. Kosaka T, Imagawa M, Seki K, Arai H, Sasaki H, Tsuji S, Asami-Odaka A, Fukushima T, Imai K, Iwatsubo T: The beta APP717 Alzheimer mutation increases the percentage of plasma amyloid-beta protein ending at A beta42(43). Neurology 1997, 48:741-745

51. Reiman EM, Quiroz YT, Fleisher AS, Chen K, Velez-Pardo C, Jimenez-Del-Rio M, Fagan AM, Shah AR, Alvarez S, Arbelaez A, Giraldo M, Acosta-Baena N, Sperling RA, Dickerson B, Stern CE, Tirado V, Munoz C, Reiman RA, Huentelman MJ, Alexander GE, Langbaum JB, Kosik KS, Tariot PN, Lopera F: 
Brain imaging and fluid biomarker analysis in young adults at genetic risk for autosomal dominant Alzheimer's disease in the presenilin 1 E280A kindred: a case-control study. Lancet Neurol 2012, 11:1048-1056.

52. Schupf N, Patel B, Silverman W, Zigman WB, Zhong N, Tycko B, Mehta PD, Mayeux R: Elevated plasma amyloid beta-peptide $1-42$ and onset of dementia in adults with Down syndrome. Neurosci Lett 2001, 301:199-203.

53. Matsuoka Y, Andrews HF, Becker AG, Gray AJ, Mehta PD, Sano MC, Dalton AJ Aisen PS: The relationship of plasma Abeta levels to dementia in aging individuals with Down syndrome. Alzheimer Dis Assoc Disord 2009, 23:315-318

54. Coppus AM, Schuur M, Vergeer J, Janssens AC, Oostra BA, Verbeek MM, van Duijn CM: Plasma beta amyloid and the risk of Alzheimer's disease in Down syndrome. Neurobiol Aging 2012, 33:1988-1994.

55. Mehta PD, Pirttila T, Mehta SP, Sersen EA, Aisen PS, Wisniewski HM: Plasma and cerebrospinal fluid levels of amyloid beta proteins 1-40 and 1-42 in Alzheimer disease. Arch Neurol 2000, 57:100-105.

56. Lewczuk P, Kornhuber J, Vanmechelen E, Peters O, Heuser I, Maier W, Jessen F, Bürger K, Hampel H, Frölich L, Henn F, Falkai P, Rüther E, Jahn H, Luckhaus Ch, Perneczky R, Schmidtke K, Schröder J, Kessler H, Pantel J, Gertz HJ, Vanderstichele H, de Meyer G, Shapiro F, Wolf S, Bibl M, Wiltfang J: Amyloid beta peptides in plasma in early diagnosis of Alzheimer's disease: A multicenter study with multiplexing. Exp Neurol 2010, 223:366-370.

57. Schupf N, Tang MX, Fukuyama H, Manly J, Andrews H, Mehta P, Ravetch J, Mayeux R: Peripheral Abeta subspecies as risk biomarkers of Alzheimer's disease. Proc Natl Acad SciU S A 2008, 105:14052-14057.

58. Graff-Radford NR, Crook JE, Lucas J, Boeve BF, Knopman DS, Ivnik RJ, Smith GE, Younkin LH, Petersen RC, Younkin SG: Association of low plasma Abeta42/Abeta40 ratios with increased imminent risk for mild cognitive impairment and Alzheimer disease. Arch Neurol 2007, 64:354-362.

59. Lambert JC, Schraen-Maschke S, Richard F, Fievet N, Rouaud O, Berr C, Dartigues JF, Tzourio C, Alperovitch A, Buee L, Amouyel P: Association of plasma amyloid beta with risk of dementia: the prospective Three-City Study. Neurology 2009, 73:847-853.

60. Shah NS, Vidal JS, Masaki K, Petrovitch H, Ross GW, Tilley C, DeMattos RB, Tracy RP, White LR, Launer LJ: Midlife blood pressure, plasma beta-amyloid, and the risk for Alzheimer disease: the Honolulu Asia Aging Study. Hypertension 2012, 59:780-786

61. van Oijen M, Hofman A, Soares HD, Koudstaal PJ, Breteler MM: Plasma Abeta(1-40) and Abeta(1-42) and the risk of dementia: a prospective casecohort study. Lancet Neurol 2006, 5:655-660.

62. Sundelöf J, Giedraitis $V$, Irizarry $M C$, Sundström J, Ingelsson E, Rönnemaa $E$, Arnlöv J, Gunnarsson MD, Hyman BT, Basun H, Ingelsson M, Lannfelt L, Kilander L: Plasma beta amyloid and the risk of Alzheimer disease and dementia in elderly men: a prospective, population-based cohort study. Arch Neurol 2008, 65:256-263.

63. Lopez OL, Kuller LH, Mehta PD, Becker JT, Gach HM, Sweet RA, Chang YF, Tracy $R$, DeKosky ST: Plasma amyloid levels and the risk of $A D$ in normal subjects in the Cardiovascular Health Study. Neurology 2008, 70:1664-1671.

64. Okereke OI, Xia W, Selkoe DJ, Grodstein F: Ten-year change in plasma amyloid beta levels and late-life cognitive decline. Arch Neurol 2009, 66:1247-1253

65. Yaffe K, Weston A, Graff-Radford NR, Satterfield S, Simonsick EM, Younkin SG, Younkin LH, Kuller L, Ayonayon HN, Ding J, Harris TB: Association of plasma beta-amyloid level and cognitive reserve with subsequent cognitive decline. JAMA 2011, 305:261-266.

66. Cosentino SA, Stern Y, Sokolov E, Scarmeas N, Manly JJ, Tang MX, Schupf N, Mayeux RP: Plasma $\beta$-amyloid and cognitive decline. Arch Neurol 2010, 67:1485-1490.
67. Locascio JJ, Fukumoto H, Yap L, Bottiglieri T, Growdon JH, Hyman BT, Irizarry MC: Plasma amyloid beta-protein and C-reactive protein in relation to the rate of progression of Alzheimer disease. Arch Neurol 2008, 65:776-785.

68. Gurol ME, Irizarry MC, Smith EE, Raju S, Diaz-Arrastia R, Bottiglieri T, Rosand J, Growdon JH, Greenberg SM: Plasma beta-amyloid and white matter lesions in AD, MCl, and cerebral amyloid angiopathy. Neurology 2006, 66:23-29.

69. Goos JD, Teunissen CE, Veerhuis R, Verwey NA, Barkhof F, Blankenstein MA, Scheltens $P$, van der Flier WM: Microbleeds relate to altered amyloid-beta metabolism in Alzheimer's disease. Neurobiol Aging 2012, 33:1011 e1011-1019.

70. Siemers ER, Dean RA, Friedrich S, Ferguson-Sells L, Gonzales C, Farlow MR, May PC: Safety, tolerability, and effects on plasma and cerebrospinal fluid amyloid-beta after inhibition of gamma-secretase. Clin Neuropharmacol 2007, 30:317-325.

71. Siemers E, Skinner M, Dean RA, Gonzales C, Satterwhite J, Farlow M, Ness D, May PC: Safety, tolerability, and changes in amyloid beta concentrations after administration of a gamma-secretase inhibitor in volunteers. Clin Neuropharmacol 2005, 28:126-132

72. Ortega F, Stott J, Visser SA, Bendtsen C: Interplay between alpha-, beta-, and gamma-secretases determines biphasic amyloid-beta protein level in the presence of a gamma-secretase inhibitor. J Biol Chem 2013, 288:785-792.

73. Imbimbo BP, Panza F, Frisardi V, Solfrizzi V, D'Onofrio G, Logroscino G, Seripa D, Pilotto A: Therapeutic intervention for Alzheimer's disease with gammasecretase inhibitors: still a viable option? Expert Opin Investig Drugs 2011, 20:325-341.

74. Galasko DR, Graff-Radford N, May S, Hendrix S, Cottrell BA, Sagi SA, Mather G, Laughlin M, Zavitz KH, Swabb E, Golde TE, Murphy MP, Koo EH: Safety, tolerability, pharmacokinetics, and Abeta levels after short-term administration of R-flurbiprofen in healthy elderly individuals. Alzheimer Dis Assoc Disord 2007, 21:292-299.

75. Li T, Huang Y, Jin S, Ye L, Rong N, Yang X, Ding Y, Cheng Z, Zhang J, Wan Z, Harrison DC, Hussain I, Hall A, Lee DH, Lau LF, Matsuoka Y: Gamma-secretase modulators do not induce Abeta-rebound and accumulation of beta-Cterminal fragment. J Neurochem 2012, 121:277-286.

76. Tong G, Wang JS, Sverdlov O, Huang SP, Slemmon R, Croop R, Castaneda L, Gu H, Wong O, Li H, Berman RM, Smith C, Albright CF, Dockens RC: Multicenter, randomized, double-blind, placebo-controlled, singleascending dose study of the oral gamma-secretase inhibitor BMS-708163 (Avagacestat): tolerability profile, pharmacokinetic parameters, and pharmacodynamic markers. Clin Ther 2012, 34:654-667.

77. Uenaka K, Nakano M, Willis BA, Friedrich S, Ferguson-Sells L, Dean RA, leiri I, Siemers ER: Comparison of pharmacokinetics, pharmacodynamics, safety, and tolerability of the amyloid beta monoclonal antibody solanezumab in Japanese and white patients with mild to moderate alzheimer disease. Clin Neuropharmacol 2012, 35:25-29.

78. Blasko I, Kemmler G, Jungwirth S, Wichart I, Krampla W, Weissgram S, Jellinger $\mathrm{K}$, Tragl KH, Fischer P: Plasma amyloid beta-42 independently predicts both late-onset depression and Alzheimer disease. Am J Geriatric Psychiatry 2010, 18:973-982.

doi:10.1186/alzrt162

Cite this article as: Toledo JB, et al.: Plasma amyloid beta measurements a desired but elusive Alzheimer's disease biomarker. Alzheimer's Research \& Therapy 2013, 5:8. 